\title{
Fractionation of wheat straw by prehydrolysis, organosolv delignification and enzymatic hydrolysis for production of sugars and lignin
}

\author{
W.J.J. Huijgen \\ A.T. Smit \\ P.J. de Wild \\ H. den Uil
}

Published in Bioresource Technology 114 (2012) 389-398 

Not for reproduction, distribution or commercial use.

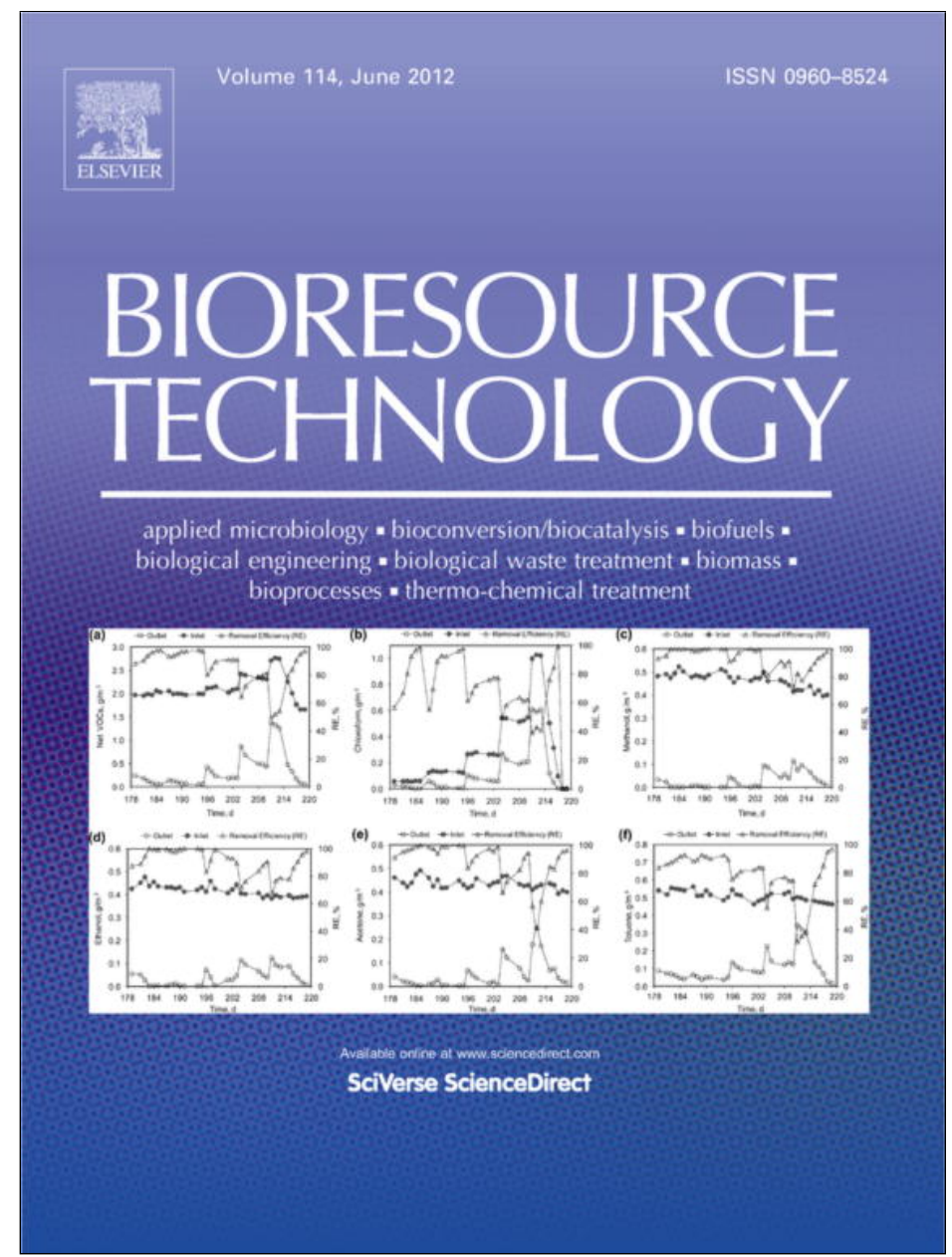

This article appeared in a journal published by Elsevier. The attached copy is furnished to the author for internal non-commercial research and education use, including for instruction at the authors institution and sharing with colleagues.

Other uses, including reproduction and distribution, or selling or licensing copies, or posting to personal, institutional or third party websites are prohibited.

In most cases authors are permitted to post their version of the article (e.g. in Word or Tex form) to their personal website or institutional repository. Authors requiring further information regarding Elsevier's archiving and manuscript policies are encouraged to visit:

http://www.elsevier.com/copyright 


\title{
Fractionation of wheat straw by prehydrolysis, organosolv delignification and enzymatic hydrolysis for production of sugars and lignin
}

\author{
W.J.J. Huijgen*, A.T. Smit, P.J. de Wild, H. den Uil \\ Energy Research Centre of The Netherlands (ECN), Biomass \& Energy Efficiency, P.O. Box 1, 1755 ZG Petten, The Netherlands
}

\section{A R T I C L E I N F O}

\section{Article history:}

Received 16 December 2011

Received in revised form 29 February 2012

Accepted 29 February 2012

Available online 7 March 2012

\section{Keywords:}

Organosolv

Pretreatment

Enzymatic hydrolysis

Prehydrolysis

Biorefining

\begin{abstract}
A B S T R A C T
Wheat straw was fractionated using a three-step biorefining approach: (1) aqueous pretreatment for hemicellulose prehydrolysis into sugars, (2) organosolv delignification, and (3) enzymatic cellulose hydrolysis into glucose. Prehydrolysis was applied to avoid degradation of hemicellulose sugars during organosolv delignification. Maximum xylose yield obtained was $67 \%$ or $0.17 \mathrm{~kg} / \mathrm{kg}$ straw (prehydrolysis: $175{ }^{\circ} \mathrm{C}, 30 \mathrm{~min}, 20 \mathrm{mM} \mathrm{H}_{2} \mathrm{SO}_{4}$ ) compared to $4 \%$ in case of organosolv without prehydrolysis (organosolv: $200^{\circ} \mathrm{C}, 60 \mathrm{~min}, 60 \% \mathrm{w} / \mathrm{w}$ aqueous ethanol). Prehydrolysis was found to reduce the lignin yield by organosolv delignification due to the formation of 'pseudo-lignin' and lignin recondensation during prehydrolysis. This reduction could partly be compensated by increasing the temperature of the organosolv delignification step. Prehydrolysis substantially improved the enzymatic cellulose digestibility from $49 \%$ after organosolv without prehydrolysis to $80 \%$ (20 FPU/g substrate). Increasing the organosolv delignification temperature to $220^{\circ} \mathrm{C}$ resulted in a maximum enzymatic glucose yield of $93 \%$ or $0.36 \mathrm{~kg} / \mathrm{kg}$ straw.
\end{abstract}

(c) 2012 Elsevier Ltd. All rights reserved.

\section{Introduction}

Biorefining is the sustainable processing of biomass into a spectrum of marketable products (food, feed, materials, and chemicals) and energy (fuels, power, and heat) (definition International Energy Agency, Bioenergy Task 42). Lignocellulosic biomass is a versatile renewable feedstock for biorefining, of which the main constituents are the biopolymers cellulose, hemicellulose, and lignin. Efficient fractionation of lignocellulosic biomass into its main constituents, such that all fractions can be valorized, is a prerequisite for an economic lignocellulosic biorefinery. In particular, the use of lignocellulosic agricultural and forestry residues for biorefineries seems promising because of high availability, relatively low costs and no direct competition with food and feed production. An agricultural residue that is often considered as a feedstock for biorefining is wheat straw (Talebnia et al., 2010). Wheat straw has also been chosen as feedstock for the work reported here.

Different lignocellulosic biorefinery concepts exist (Kamm et al., 2006). Within the so-called sugar platform, the cellulose fraction is first hydrolyzed into glucose, which can then be converted into e.g. bioethanol by fermentation. In case of enzymatic cellulose hydrolysis, direct hydrolysis of lignocellulose is very inefficient and pretreatment is required to render the cellulose fibrils more accessible to enzymes (Hendriks and Zeeman, 2009; Wyman et al., 2005). The aims of the pretreatment step include delignification,

\footnotetext{
* Corresponding author. Tel.: +31 224568162.

E-mail address: huijgen@ecn.nl (W.J.J. Huijgen).
}

hemicellulose removal and reduction of the degree of polymerization and crystallinity of the cellulose fraction (Mosier et al., 2005; Taherzadeh and Karimi, 2008).

Organosolv is a pretreatment technology which has been reported to produce readily hydrolysable cellulose substrates in addition to lignin (Pan et al., 2005a; Zhao et al., 2009). The coproduction of a high-purity lignin stream is a major advantage of organosolv compared to other pretreatment routes like steam explosion and mild acid pretreatment. Lignin is a potential renewable source for aromatic chemicals, like phenolics, and performance products, like resins (Zakzeski et al., 2010). Vice versa, valorization of co-products (lignin as well as hemicellulose derivatives) is essential for an economic organosolv process (Pan et al., 2005a).

Hemicellulose is the most reactive of the three major structural constituents of lignocellulosic biomass. In this study, the aim is to convert wheat straw hemicellulose into sugars. A drawback of the organosolv process is that the conditions required to delignify lignocellulosic feedstocks may lead to low yields of hemicellulose sugars due to degradation and subsequent formation of humins and condensation products with lignin (Huijgen et al., 2010; Zhao et al., 2009). In earlier work on autocatalytic acetone-based organosolv pretreatment of wheat straw, we reported that, at conditions yielding maximum enzymatic digestibility $\left(205^{\circ} \mathrm{C}\right)$, the yield of the major hemicellulose sugar xylose was only $~ 4 \%$ of its theoretical maximum or $1 \% \mathrm{w} / \mathrm{w}$ raw wheat straw (Huijgen et al., 2010). The yield of furfural was only slightly higher.

A possible approach to avoid degradation reactions of hemicellulose sugars is prehydrolysis of the hemicellulose fraction into 
sugars prior to organosolv delignification. In this way, the hemicellulose fraction does not have to be exposed to the relatively severe process conditions required for delignification. In general, aqueous treatment has been widely studied as a means to convert hemicellulose into sugars (as well as other chemicals such as furfural and acetic acid) (Carvalheiro et al., 2008; Garrote et al., 1999). In addition, aqueous treatment leads to the removal of part of the extractives and water-soluble ash minerals such as the alkalis. The resulting solid residue from the aqueous treatment consists mainly of lignin and cellulose and contains less inorganic and organic extractives compared to the starting material. As a consequence, this "extractive-poor" lignin-cellulose residue seems a better feedstock for the production of pure lignin and cellulose by organosolv delignification than the raw biomass.

During the last years, experimental studies on hydrolysis of hemicellulose prior to organosolv treatment have been published with steam (Chen and Liu, 2007), dilute acid presoaking (Brosse et al., 2009) and hydrothermal pretreatment (El Hage et al., 2010; Romaní et al., 2011; Ruiz et al., 2011). However, in most of these studies the prehydrolysis-organosolv fractionation approach is not compared with direct organosolv treatment of the biomass. Only El Hage et al. made such a comparison, but for a different type of biomass, i.e. Miscanthus (El Hage et al., 2010). Such a comparison is required to elucidate the influence of the prehydrolysis step on the delignification during subsequent organosolv treatment and the resulting enzymatic digestibility of the cellulose fraction.

In this paper, we present a study on the fractionation of wheat straw by aqueous pretreatment (prehydrolysis), organosolv delignification and enzymatic hydrolysis. The aim of the prehydrolysis step is to hydrolyze the hemicellulose fraction into sugars, xylose in particular. During the organosolv step, the prehydrolyzed wheat straw is delignified with the help of ethanol as solvent and a cellulose-enriched substrate for enzymatic hydrolysis is produced. Results of prehydrolysis-organosolv fractionation are compared with direct organosolv treatment. The objective of the research described in this paper was to study the effectiveness of the prehydrolysis step and its influence on organosolv delignification and enzymatic digestibility of the resulting pretreated wheat straw.

\section{Methods}

\subsection{Materials}

\subsubsection{Raw material}

Wheat straw (cut to $<2 \mathrm{~cm}$ ) was provided by Abengoa Bioenergy New Technologies, Spain, in the framework of the EU-FP6 project BioSynergy. The average moisture content of the raw material was $\sim 8 \% \mathrm{w} / \mathrm{w}$. The summative composition of the wheat straw was (\% w/w dry biomass): extractives, $11.2 \pm 1.2\left(\mathrm{H}_{2} \mathrm{O}\right)$ and $2.0 \pm 0.0$ (ethanol); glucan, $34.6 \pm 1.0$; xylan, $21.5 \pm 0.7$; arabinan, $2.1 \pm 0.1$; galactan, $0.5 \pm 0.0$; mannan, $0.2 \pm 0.1$; acid insoluble lignin, $15.1 \pm 0.1$; and acid soluble lignin, $1.0 \pm 0.0$ (Huijgen et al., 2010). The ash content of the straw was $8.5 \% \mathrm{w} / \mathrm{w}$ dry biomass. The elemental composition of the wheat straw was (\% w/w dry biomass): C, 43.8; O, 41.7; H, 5.4; $\mathrm{Si}, 2.4 ; \mathrm{K}, 1.4 ; \mathrm{Cl}, 0.5 ; \mathrm{N}, 0.2$; and $\mathrm{Ca}$, 0.2 (other elements <0.1) (Huijgen et al., 2010).

\subsubsection{Chemicals and enzyme}

Ethanol 96\% was purchased from Merck, Germany with a specified purity of $92.6-95.2 \% \mathrm{w} / \mathrm{w}$. An average purity of $94 \% \mathrm{w} / \mathrm{w}$ was used in the calculations. The enzyme mixture that was used for enzymatic cellulose hydrolysis (Accellerase 1500) was kindly provided by Genencor, Rochester, NY. The sugar content of the enzyme mixture was found to be negligible for calculation of the enzymatic glucose yields. All chemicals and enzymes were used without further purification.

\subsection{Fractionation}

Table 1 gives an overview of the conducted fractionation experiments. Fractionation experiments consisted of two steps: (1) aqueous pretreatment (prehydrolysis) and (2) organosolv delignification. Fig. 1 shows a scheme of the experiments performed. Both process steps were performed in an autoclave reactor (2 L Hastelloy Kiloclave, Büchi Glas Uster AG, $\mathrm{CH}$ ) using an anchor stirrer at a rate of $100 \mathrm{rpm}$.

Experiments were carried out in two series (series 1: experiments 1-4 and 9-11, series 2: experiments 5-8). A typical temperature profile of the autoclave reactor is given in Fig. 2. The temperature profile of the reactor in both series differed to some extent due to changes made in the control software. For example, heating to $175^{\circ} \mathrm{C}$ was about $13 \mathrm{~min}$ faster in series 1 than in series 2 (prehydrolysis step). Repetition of experiment 2 using the heating profile of the second series showed that the changes in the temperature profile of the reactor had limited effect on the results compared to the effects of the process parameters, as varied in this study (data not shown).

\subsubsection{Prehydrolysis}

Wheat straw was suspended in acidified water $(0-20 \mathrm{mM}$ $\mathrm{H}_{2} \mathrm{SO}_{4}$, liquid-to-solid (L/S) ratio $=7.5 \mathrm{~L} / \mathrm{kg}$ dry biomass) and heated in the autoclave reactor to a reaction temperature of 160 $190{ }^{\circ} \mathrm{C}$. After $30-120 \mathrm{~min}$ at the reaction temperature, the autoclave was cooled down to a temperature below $40^{\circ} \mathrm{C}$. The product slurry was filtered quantitatively over a Whatman GF/D-filter. The solid product was washed with demineralized water. The two resulting liquors were combined and stored in a refrigerator for analysis. The washed solid was divided in two portions. A part of the solid was dried at $50{ }^{\circ} \mathrm{C}$ under vacuum for analysis and determination of the pulp yield. The rest of the solid product was kept overnight in a refrigerator for organosolv fractionation.

\subsubsection{Organosolv}

The pulp resulting from the prehydrolysis step was mixed with demineralized water and ethanol to obtain a slurry with a L/S-ratio of $10 \mathrm{~L}$ solvent $/ \mathrm{kg} \mathrm{dw}$ biomass and an ethanol-water ratio of $60: 40 \% \mathrm{w} / \mathrm{w}$. After heating the reactor to the reaction temperature $\left(190-220^{\circ} \mathrm{C}\right)$, the reactor was kept isothermal during the reaction time (t, $60 \mathrm{~min}$ ), and subsequently cooled down to below $40^{\circ} \mathrm{C}$.

After organosolv treatment, the product suspension was filtered quantitatively over a Whatman GF/D-filter. The solid fraction remaining after organosolv was washed with $60 \% \mathrm{w} / \mathrm{w}$ aqueous ethanol and divided into two portions. One part was stored in a refrigerator for enzymatic hydrolysis tests. The other part was washed with water and dried overnight under vacuum at $50^{\circ} \mathrm{C}$ for analysis and determination of the pulp yield. The 'organosolv liquor' and the first washing liquor were combined and stored in a refrigerator for analysis and lignin recovery. Lignin was precipitated from the liquor upon dilution with refrigerated water (water:solution 3:1 w/w) following a procedure that has been described earlier (Huijgen et al., 2010).

\subsection{Analyses}

\subsubsection{Prehydrolysis and organosolv liquors}

The prehydrolysis and organosolv liquors were analyzed for their $\mathrm{pH}$ and content of monomeric and oligomeric sugars, sugar degradation products and organic acids. Analysis of monomeric sugars was performed with High Performance Anion Exchange Chromatography with Pulsed Amperometric Detection (HPAEC- 
Table 1

Experiments.

\begin{tabular}{|c|c|c|c|c|c|c|c|}
\hline \multirow[t]{2}{*}{ Experimental series } & \multicolumn{2}{|c|}{ Experiment $^{\mathrm{a}}$} & \multicolumn{5}{|c|}{ Process conditions } \\
\hline & & & Feedstock & Solvent ${ }^{\mathrm{b}}$ & $\mathrm{T}\left({ }^{\circ} \mathrm{C}\right)$ & $t(\min )$ & {$\left[\mathrm{H}_{2} \mathrm{SO}_{4}\right](\mathrm{mM})$} \\
\hline Organosolv w/o prehydrolysis & 1 & & Straw & $60 \% \mathrm{EtOH}$ & 200 & 60 & 0 \\
\hline \multirow[t]{2}{*}{ Organosolv with prehydrolysis } & 2 & A & Straw & $\mathrm{H}_{2} \mathrm{O}$ & 175 & 30 & 0 \\
\hline & & B & Pulp 2A & $60 \% \mathrm{EtOH}$ & 200 & 60 & 0 \\
\hline \multirow[t]{4}{*}{$\mathrm{T}$ prehydrolysis } & 3 & A & Straw & $\mathrm{H}_{2} \mathrm{O}$ & 160 & 30 & 0 \\
\hline & & B & Pulp 3A & $60 \% \mathrm{EtOH}$ & 200 & 60 & 0 \\
\hline & 4 & A & Straw & $\mathrm{H}_{2} \mathrm{O}$ & 190 & 30 & 0 \\
\hline & & B & Pulp 4A & $60 \% \mathrm{EtOH}$ & 200 & 60 & 0 \\
\hline \multirow[t]{4}{*}{ t prehydrolysis } & 5 & A & Straw & $\mathrm{H}_{2} \mathrm{O}$ & 175 & 60 & 0 \\
\hline & & B & Pulp 5A & $60 \% \mathrm{EtOH}$ & 200 & 60 & 0 \\
\hline & 6 & A & Straw & $\mathrm{H}_{2} \mathrm{O}$ & 175 & 120 & 0 \\
\hline & & B & Pulp 6A & $60 \% \mathrm{EtOH}$ & 200 & 60 & 0 \\
\hline \multirow[t]{4}{*}[\mathrm{H}_{2}\mathrm{SO}_{4}]{ prehydrolysis } & 7 & A & Straw & $\mathrm{H}_{2} \mathrm{O}$ & 175 & 30 & 10 \\
\hline & & B & Pulp 7A & $60 \% \mathrm{EtOH}$ & 200 & 60 & 0 \\
\hline & 8 & A & Straw & $\mathrm{H}_{2} \mathrm{O}$ & 175 & 30 & 20 \\
\hline & & B & Pulp 8A & $60 \% \mathrm{EtOH}$ & 200 & 60 & 0 \\
\hline \multirow[t]{6}{*}{ T organosolv } & 9 & A & Straw & $\mathrm{H}_{2} \mathrm{O}$ & 175 & 30 & 0 \\
\hline & & B & Pulp 9A & $60 \% \mathrm{EtOH}$ & 190 & 60 & 0 \\
\hline & 10 & A & Straw & $\mathrm{H}_{2} \mathrm{O}$ & 175 & 30 & 0 \\
\hline & & B & Pulp 10A & $60 \% \mathrm{EtOH}$ & 210 & 60 & 0 \\
\hline & 11 & A & Straw & $\mathrm{H}_{2} \mathrm{O}$ & 175 & 30 & 0 \\
\hline & & B & Pulp 11A & $60 \% \mathrm{EtOH}$ & 220 & 60 & 0 \\
\hline
\end{tabular}

a $A=$ prehydrolysis step. $\mathrm{B}=$ organosolv delignification step.

b $60 \% \mathrm{EtOH}=60 \% \mathrm{w} / \mathrm{w}$ aqueous ethanol.
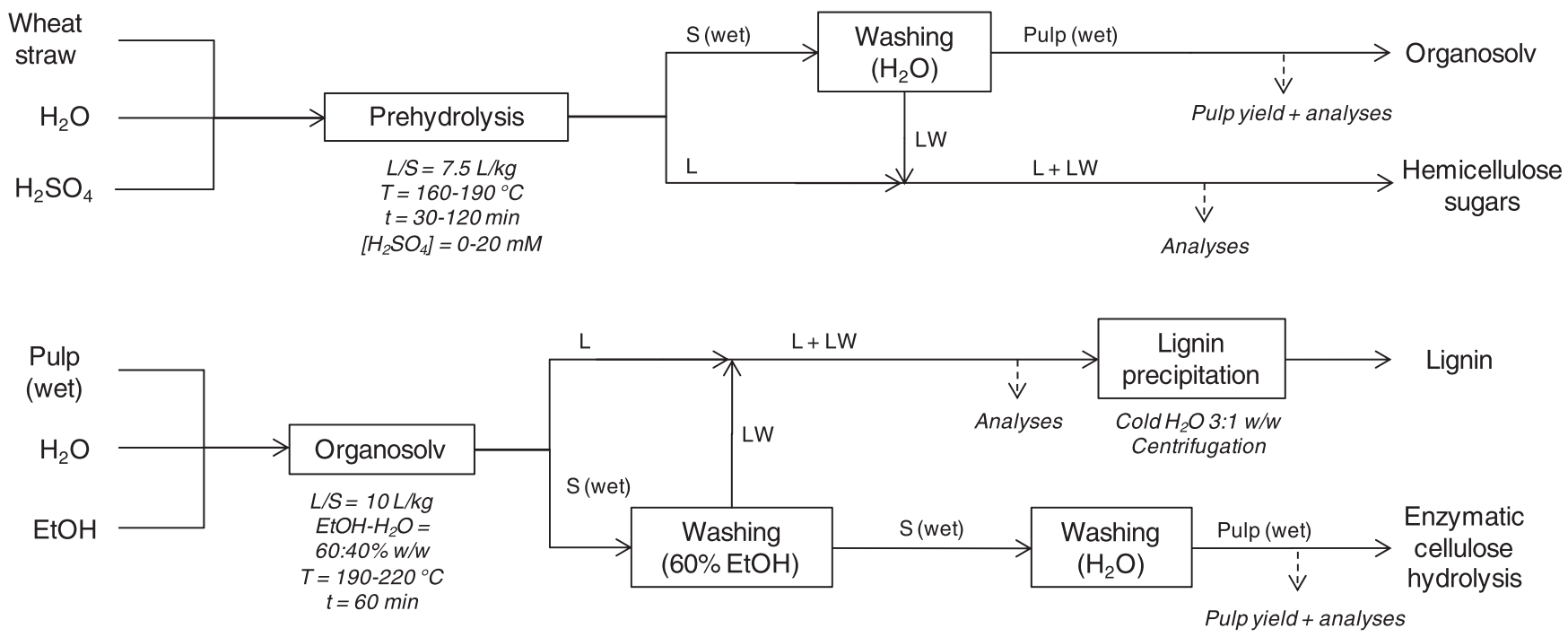

Fig. 1. Schematic representation of experiments.

PAD, ICS3000, Dionex, Sunnyvale, CA) equipped with a CarboPac PA1 column and post-column addition of $0.2 \mathrm{~mL} / \mathrm{min} 0.25 \mathrm{M}$ $\mathrm{NaOH}$. A gradient of $\mathrm{NaOH}$ was used as eluent $(0.25 \mathrm{~mL} / \mathrm{min})$ : $15 \mathrm{mM}$ (0-2 min), $0 \mathrm{mM}$ (2-30 min), from 0 to $200 \mathrm{mM}$ (30$35 \mathrm{~min}$ ), $200 \mathrm{mM}$ (35-40 min), from 200 to $15 \mathrm{mM}$ (40-45 min), and finally $15 \mathrm{mM}(45-50 \mathrm{~min})$. Liquors resulting from the first series of experiments were analyzed without the use of an internal standard. Deviations due to drift in the detector's response within a series of analyses were estimated to be $<2.5 \%$ for these liquors based on the response of monomeric sugar calibration standards before and after each measurement series. Liquors resulting from the second series of experiments were analyzed using lactose as an internal standard to compensate for the detector's drift. The sugar analyses were performed both directly and following posthydrolysis of the sample (post-hydrolysis conditions: $1 \mathrm{M} \mathrm{H}_{2} \mathrm{SO}_{4}$, $100{ }^{\circ} \mathrm{C}, 2 \mathrm{~h}$ ). The concentration of oligomeric sugars in the liquors was calculated from the difference between the two analyses.
Analysis of the sugar dehydration products HMF (5-(hydroxymethyl)-2-furaldehyde) and furfural (2-furaldehyde) as well as acetic, formic, and levulinic acid was performed with HPLC-RI/UV (with BIO RAD Aminex HPX-87H column, $65^{\circ} \mathrm{C}, 5 \mathrm{mM} \mathrm{H}_{2} \mathrm{SO}_{4}$, $0.60 \mathrm{~mL} / \mathrm{min}$ ).

\subsubsection{Moisture and ash content solids}

The moisture and ash contents of solid samples were measured according to the protocols NREL/TP-510-42621 and 42622, respectively (National Renewable Energy Laboratory (NREL), 2009). The moisture content was measured with a halogen moisture analyzer (Mettler Toledo HR83). The ash content was measured by combustion at $550{ }^{\circ} \mathrm{C}$.

\subsubsection{Summative composition fractionated solids}

The summative composition of solids was analyzed using procedures described in earlier work (Huijgen et al., 2010, 2011). 


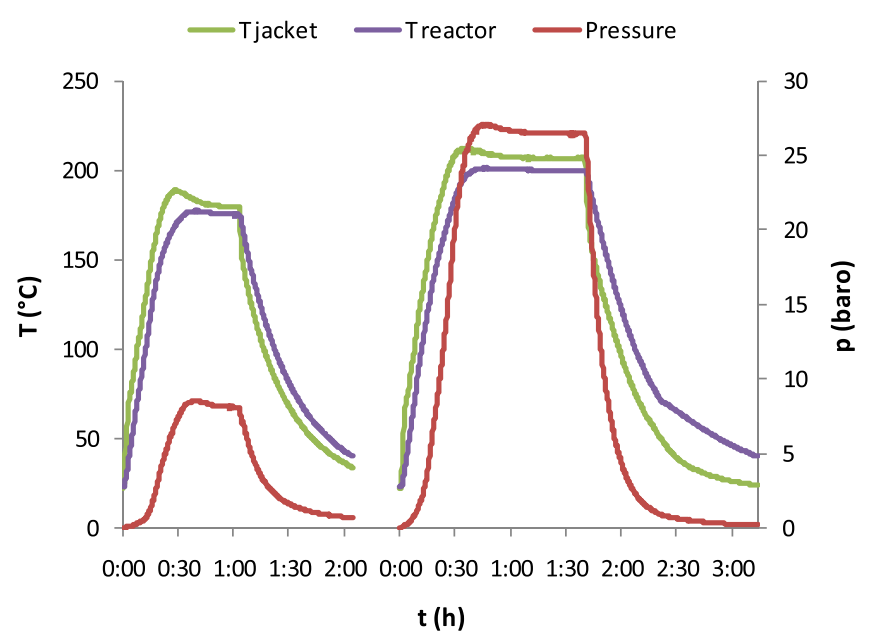

Fig. 2. Temperature and pressure profiles of the prehydrolysis and organosolv process steps (experiments $2 \mathrm{~A}$ and $\mathrm{B}$ ).

These procedures are modified versions of the NREL standard biomass analytical procedures (National Renewable Energy Laboratory (NREL), 2009). In short, the content of lignin, hemicelluloses, and cellulose was determined in duplicate by hydrolysis. The sample was milled with a cutting mill and hydrolyzed in two steps: (1) $12 \mathrm{M}(72 \% \mathrm{w} / \mathrm{w}) \mathrm{H}_{2} \mathrm{SO}_{4}\left(30^{\circ} \mathrm{C}, 1 \mathrm{~h}\right)$ and (2) $1.2 \mathrm{M} \mathrm{H}_{2} \mathrm{SO}_{4}\left(100{ }^{\circ} \mathrm{C}\right.$, $3 \mathrm{~h})$. The solid residue was determined gravimetrically and its ash content was measured. The acid-insoluble lignin (AIL) content was based on the amount of ash-free residue. Finally, the hydrolysate was analyzed for monomeric sugars (with HPAEC-PAD as described in Section 2.3.1, sample neutralized first with $\mathrm{BaCO}_{3}$ ) as well as acid-soluble lignin (ASL, UV-VIS absorption at $205 \mathrm{~nm}$, absorption coefficient of $110 \mathrm{Lg}^{-1} \mathrm{~cm}^{-1}$ used according to TAPPI UM-250 (Technical Association of the Pulp (TAPPI), 1976).

In the NREL protocols, the sugar concentrations in the hydrolysates are corrected for potential sugar degradation during the hydrolysis steps by the use of 'sugar recovery standards' (National Renewable Energy Laboratory (NREL), 2009). However, this correction is known to probably be an overestimation (Sluiter et al., 2010). Therefore, no correction was applied in this study although this might have lead to an underestimation of the xylan and glucan contents of the solids. The main consequence of this is that the enzymatic glucose yields might be slightly overestimated.

\subsubsection{Enzymatic digestibility}

The enzymatic digestibility of (pretreated) wheat straw was measured in duplicate according to NREL/TP-510-42629 (National Renewable Energy Laboratory (NREL), 2009) as described in earlier work (Huijgen et al., 2010, 2011). All pretreated wheat straw samples were enzymatically hydrolyzed without intermediate drying. Samples were kept until enzymatic hydrolysis in $60 \% \mathrm{w} / \mathrm{w}$ aqueous ethanol in a refrigerator to prevent bacterial growth. Before enzymatic hydrolysis, pulps were thoroughly washed with water to remove any ethanol.

A suspension of $1.5 \mathrm{~g}$ dw biomass in $50 \mathrm{~mL} 0.05 \mathrm{M} \mathrm{Na}$-acetate buffer (pH 4.8) was shaken in an incubator. Thirty microliter PenStrep ( $5000 \mathrm{U} / \mathrm{mL}$ penicillin and $5 \mathrm{mg} / \mathrm{mL}$ streptomycin) was added as an antibiotic to eliminate potential bacterial growth. After heating to $50{ }^{\circ} \mathrm{C}$, enzyme was added at $20 \mathrm{FPU} / \mathrm{g}$ dry substrate and incubation was continued for $72 \mathrm{~h}$. At fixed intervals, samples were taken from the mixture for glucose determination. Glucose concentrations were determined with a colorimetric protocol as reported earlier (Huijgen et al., 2010). The enzymatic glucose yield was calculated on the basis of the maximum glucose concentration over time in the hydrolysate.

\subsection{Error analysis}

Prehydrolysis at initial conditions $\left(175^{\circ} \mathrm{C}, 30 \mathrm{~min}\right.$, no acid $)$ was performed four times: experiments $2 \mathrm{~A}, 9 \mathrm{~A}, 10 \mathrm{~A}$, and 11A (Table 1 ). The standard deviations in the results of these experiments were used as an estimation of the error made in all experiments

Table 2

Solids: pulp yield and summative composition of pulps and raw wheat straw.

\begin{tabular}{|c|c|c|c|c|c|c|c|c|c|c|c|}
\hline \multicolumn{2}{|c|}{ Experiment $^{\mathrm{a}}$} & \multirow[t]{2}{*}{ Pulp yield $(\mathrm{dw} \%)^{b}$} & \multicolumn{9}{|c|}{ Composition (\% w/w dry solid $)^{c}$} \\
\hline & & & AIL & ASL & Ara & Xyl & Man & Gal & Glc & Ash & Total \\
\hline \multicolumn{3}{|c|}{ Wheat straw ${ }^{d}$} & 15.1 & 1.0 & 2.1 & 21.5 & 0.2 & 0.5 & 34.6 & 8.5 & 96.9 \\
\hline 1 & & 57.9 & 8.5 & 0.6 & 0.2 & 18.3 & e & 0.1 & 57.1 & 9.9 & 94.6 \\
\hline \multirow[t]{2}{*}{2} & A & 69.4 & 23.4 & 0.9 & 0.5 & 13.4 & & 0.2 & 47.7 & 7.1 & 93.1 \\
\hline & B & $74.5(51.7)$ & 11.9 & 0.4 & 0.1 & 11.1 & & & 63.5 & 9.2 & 96.2 \\
\hline \multirow[t]{2}{*}{3} & A & 84.4 & 20.7 & 1.1 & 1.4 & 21.4 & & 0.4 & 39.0 & 6.2 & 90.3 \\
\hline & $\mathrm{B}$ & $66.2(55.9)$ & 9.7 & 0.6 & 0.2 & 16.6 & & & 57.6 & 8.8 & 93.5 \\
\hline \multirow[t]{2}{*}{4} & A & 61.7 & 29.1 & 1.0 & 0.1 & 3.9 & & 0.1 & 53.6 & 8.7 & 96.4 \\
\hline & $\mathrm{B}$ & $82.9(51.2)$ & 17.5 & 0.3 & & 3.8 & & & 64.0 & 10.4 & 96.0 \\
\hline \multirow[t]{2}{*}{5} & A & 63.1 & 26.2 & 0.8 & & 8.5 & & & 50.6 & 9.2 & 95.3 \\
\hline & B & $81.5(51.4)$ & 15.4 & 0.4 & & 7.4 & & & 60.5 & 10.6 & 94.3 \\
\hline \multirow[t]{2}{*}{6} & A & 63.9 & 29.6 & 1.0 & & 4.9 & & & 50.1 & 8.2 & 93.8 \\
\hline & $\mathrm{B}$ & $83.6(53.4)$ & 19.4 & 0.3 & & 5.3 & & & 60.2 & 9.7 & 94.9 \\
\hline \multirow[t]{2}{*}{7} & A & 62.8 & 25.2 & 0.8 & 0.3 & 10.2 & & & 51.1 & 8.3 & 95.9 \\
\hline & B & $73.6(46.2)$ & 13.3 & 0.4 & & 6.6 & & & 63.8 & 10.6 & 94.7 \\
\hline \multirow[t]{2}{*}{8} & A & 58.6 & 27.0 & 0.7 & & 6.2 & & & 53.9 & 8.7 & 96.5 \\
\hline & $\mathrm{B}$ & $84.3(49.4)$ & 14.9 & 0.3 & & 5.0 & & & 62.6 & 11.0 & 93.8 \\
\hline \multirow[t]{2}{*}{9} & A & 69.9 & 23.1 & 0.9 & 0.5 & 13.4 & & 0.2 & 48.4 & 8.0 & 94.5 \\
\hline & B & $81.0(56.6)$ & 13.4 & 0.5 & 0.2 & 11.8 & & 0.1 & 58.7 & 9.8 & 94.6 \\
\hline \multirow[t]{2}{*}{10} & A & 69.2 & 23.0 & 0.8 & 0.5 & 13.7 & & 0.2 & 49.3 & 8.1 & 95.6 \\
\hline & $\mathrm{B}$ & $73.4(50.8)$ & 10.5 & 0.4 & & 8.7 & & & 66.4 & 10.7 & 96.6 \\
\hline \multirow[t]{2}{*}{11} & A & 69.1 & 23.1 & 0.9 & 0.5 & 13.5 & & 0.2 & 48.8 & 8.1 & 95.0 \\
\hline & B & $68.7(47.5)$ & 10.2 & 0.4 & & 6.7 & & & 68.5 & 10.5 & 96.3 \\
\hline
\end{tabular}

a $A=$ prehydrolysis step. $B=$ organosolv delignification step.

b dw: dry weight. Pulp yields of individual process steps given. Overall pulp yield of prehydrolysis and organosolv delignification given between brackets.

c Average of duplicate analyses. Abbreviations used: arabinan (Ara), xylan (Xyl), mannan (Man), galactan (Gal), glucan (Glc), acid insoluble lignin (AIL), and acid soluble lignin (ASL).

d (Huijgen et al., 2010). Extractives: $11.2 \% \mathrm{w} / \mathrm{w}\left(\mathrm{H}_{2} \mathrm{O}\right)$ and $2.0 \% \mathrm{w} / \mathrm{w}(\mathrm{EtOH})$.

e Empty cell: below detection limit. 
performed. The average pulp yield was $69.4 \pm 0.4 \% \mathrm{w} / \mathrm{w}$ dry biomass. The standard deviations calculated for the glucan, xylan, AIL, and ash contents of the pretreated solid were $0.7 \%, 0.2 \%$, $0.2 \%$, and $0.5 \% \mathrm{w} / \mathrm{w}$ dry biomass, respectively. The absolute standard deviations for the resulting xylan, glucan, and lignin recovery in the pretreated solid were $0.5 \%, 1.2 \%$, and $1.0 \%$, respectively. The standard deviation for the yield of monomeric and oligomeric xylose and furfural were $0.4 \%, 0.8 \%$, and $0.4 \%$ of their theoretical maximum yield, respectively.

For the enzymatic digestibility, an estimation of the experimental error was made based on a reference sample that was included in every series of enzymatic hydrolysis tests performed. The standard deviation found for the glucose concentration after $72 \mathrm{~h}$ was $3.7 \%(n=9)$. Similar experimental errors have been reported in earlier work (Huijgen et al., 2010, 2011).

\section{Results and discussion}

\subsection{Definitions}

Pulp yield and composition of wheat straw and pulps are expressed in $\% \mathrm{w} / \mathrm{w}$ dry biomass. Delignification degree and lignin yield are given as \% w/w of the amount of lignin present in the raw wheat straw. The yields of xylan and glucan derivatives, such as sugars and furans, are expressed in \% of their theoretical maximum based on the composition of the raw wheat straw, respectively. Enzymatic digestibility is determined as \% of the theoretical maximum glucose yield based on the glucan content of the substrate.

\subsection{Organosolv fractionation without prehydrolysis}

First, a reference organosolv fractionation experiment was carried out without prehydrolysis (experiment 1 , Table 1 ). The process conditions of this reference experiment $\left(200^{\circ} \mathrm{C}, 60 \% \mathrm{w} / \mathrm{w}\right.$ ethanolwater, $10 \mathrm{~L} / \mathrm{kg}$ dry wheat straw, $60 \mathrm{~min}$, no acid) were selected based on earlier studies (Diaz et al., 2011; Huijgen et al., 2010).

Table 2 shows the yield and composition of the resulting pulp. The pulp yield is $57.9 \%$ and the resulting pulp is enriched in glucan compared to the raw material ( 57.1 vs $34.6 \%$ ). The lignin and xylan contents decrease from $16.1 \%$ to $9.1 \%$ and from $21.5 \%$ to $18.3 \%$, respectively. In other words, $67 \%$ of the lignin and $51 \%$ of the xylan are removed from the wheat straw during the organosolv treatment (Figs. 3 and 4). At the same time, 95\% of the glucan remains in the solid fraction (Fig. 5). In spite of the 51\% xylan removal, the xylose yield is only $4 \%$ based on the xylan content of the feedstock. This xylose is mainly present in the form of oligomers (Table 3 ). In total, residual xylan and identified xylan derivatives (including a furfural yield of $2 \%$ ) account for only $56 \%$ of the original xylan in the feedstock (Fig. 3 ). The remaining $44 \%$ has reacted into unidentified products including possibly condensates with lignin (Huijgen et al., 2010). The $\mathrm{pH}$ of the organosolv liquor is 4.9 (Table 3). The
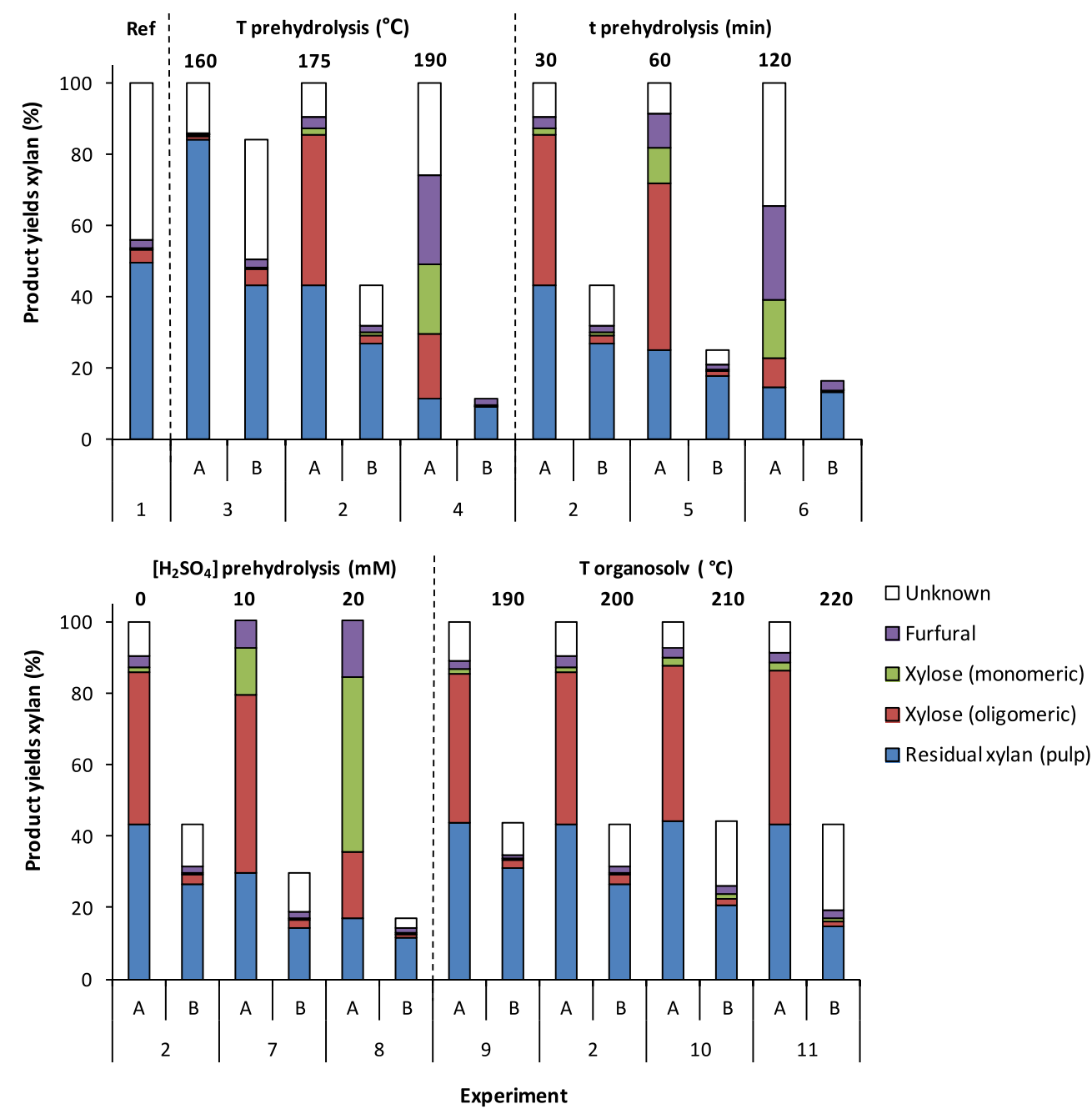

Fig. 3. Product distribution of xylan based on xylan content raw wheat straw. Yields:\% of theoretical maximum. (A) prehydrolysis. (B) organosolv delignification. 

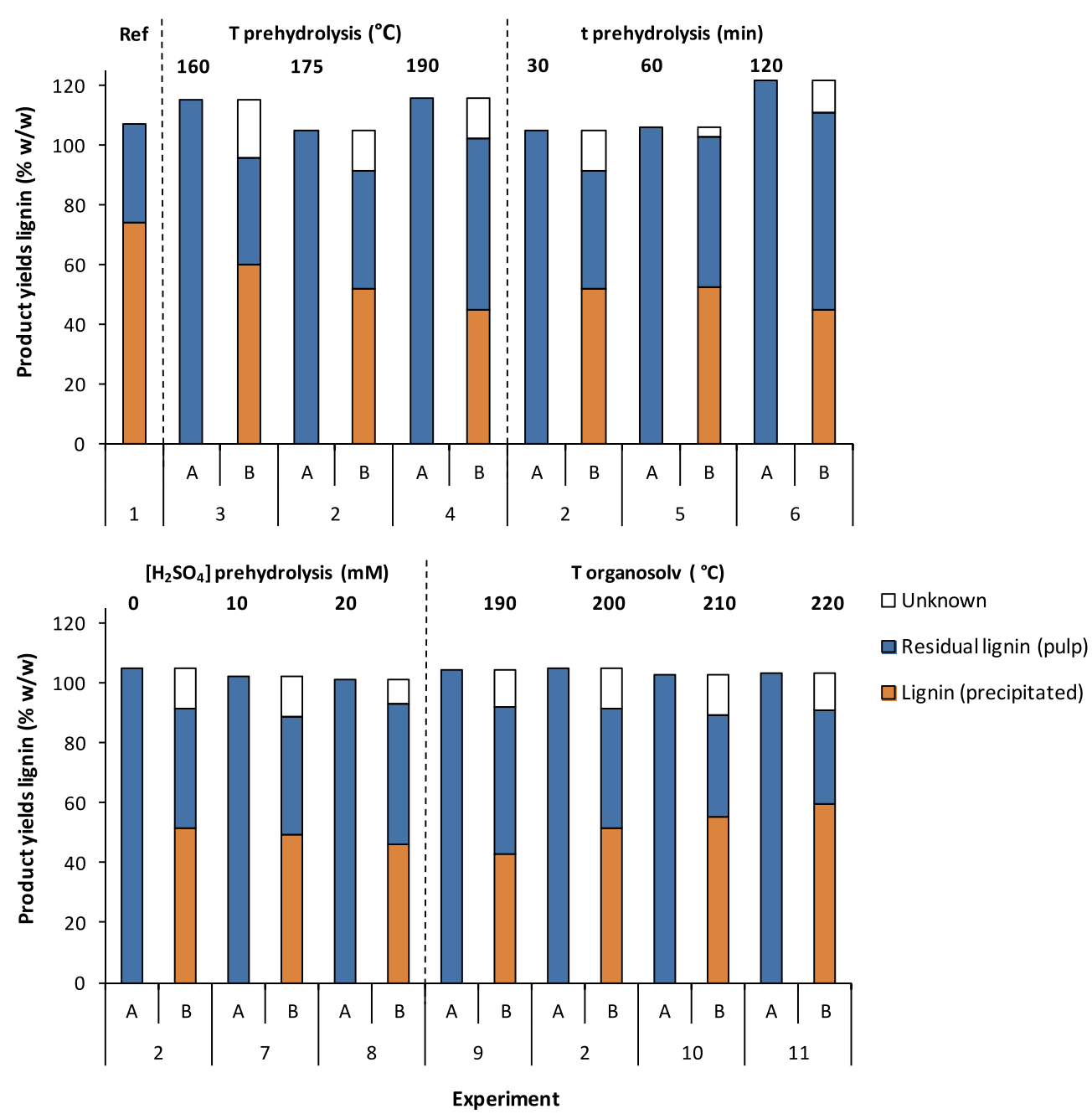

Fig. 4. Product distribution of lignin based on lignin content raw wheat straw. (A) prehydrolysis. (B) organosolv delignification and lignin precipitation from the organosolv liquor.

enzymatic digestibility of the produced cellulose-enriched pulp is $51 \%$ compared to $15 \%$ for untreated raw wheat straw (Fig. 6).

\subsection{Prehydrolysis prior to organosolv}

In experiments 2-8 prehydrolysis was performed prior to organosolv delignification. Organosolv was performed at identical conditions as used for the organosolv experiment without prehydrolysis (Section 3.2). The influence of temperature, reaction time and addition of $\mathrm{H}_{2} \mathrm{SO}_{4}$ as catalyst were studied around the initial experiment (experiment 2, Table 1 ). The conditions of this experiment were selected based on earlier work on aqueous pretreatment (Huijgen et al., 2010; Wild de et al., 2009) and the influence of the reaction temperature (Section 3.3.1).

\subsubsection{Temperature}

The prehydrolysis step was performed at 160,175 and $190{ }^{\circ} \mathrm{C}$ (experiments 3, 2 and 4). Prehydrolysis effectively removes the xylan fraction. At $190^{\circ} \mathrm{C}$, the xylan content of the prehydrolyzed pulp is only $3.9 \%$ corresponding to $89 \%$ xylan removal. However, at $190^{\circ} \mathrm{C}$ a substantial part of the xylose reacts further to furfural (yield 25\%) and degradation products like humins and lignin-furfural condensates (loss xylan: 26\%, Fig. 3). The maximum yield of monomeric and oligomeric xylose $\left(44 \%\right.$ in total) occurs at $175^{\circ} \mathrm{C}$.
At this condition, almost all (96\%) xylose is present in oligomeric form (Fig. 3).

The amount of lignin recovered in the pulp apparently increases compared to the lignin present in the raw wheat straw. At $190{ }^{\circ} \mathrm{C}$, the lignin recovery is $115 \%$ (Fig. 4). This effect is most probably due to formation of 'pseudo-lignin' (i.e., products, such as lignin-extractives, lignin-protein, and lignin-furfural condensation products, that cannot be distinguished from Klason lignin by the analytical method used (Garrote et al., 1999; Huijgen et al., 2010; Pan et al., 2005b). Besides, formation of lignin recondensation products during aqueous thermal treatment of biomass has been reported extensively in literature ( $\mathrm{Li}$ and Gellerstedt, 2008; Li et al., 2007). The formation of these products is known to occur especially at longer reaction times (typical for the use of a batch reactor because of the heating and cooling times involved) (Aravamuthan et al., 1989; Lora and Wayman, 1978). In flow-through reactor systems with short contact times lignocellulosic biomass can actually be partly delignified using aqueous pretreatment (Liu and Wyman, 2004).

The use of a prehydrolysis step influences the delignification during the subsequent organosolv step as well as the enzymatic digestibility of the resulting pulp. The delignification as well as the lignin yield by precipitation (both based on raw wheat straw, Fig. 4) decrease compared to the reference organosolv case without prehydrolysis in spite of the lower $\mathrm{pH}$ of the organosolv liquor 

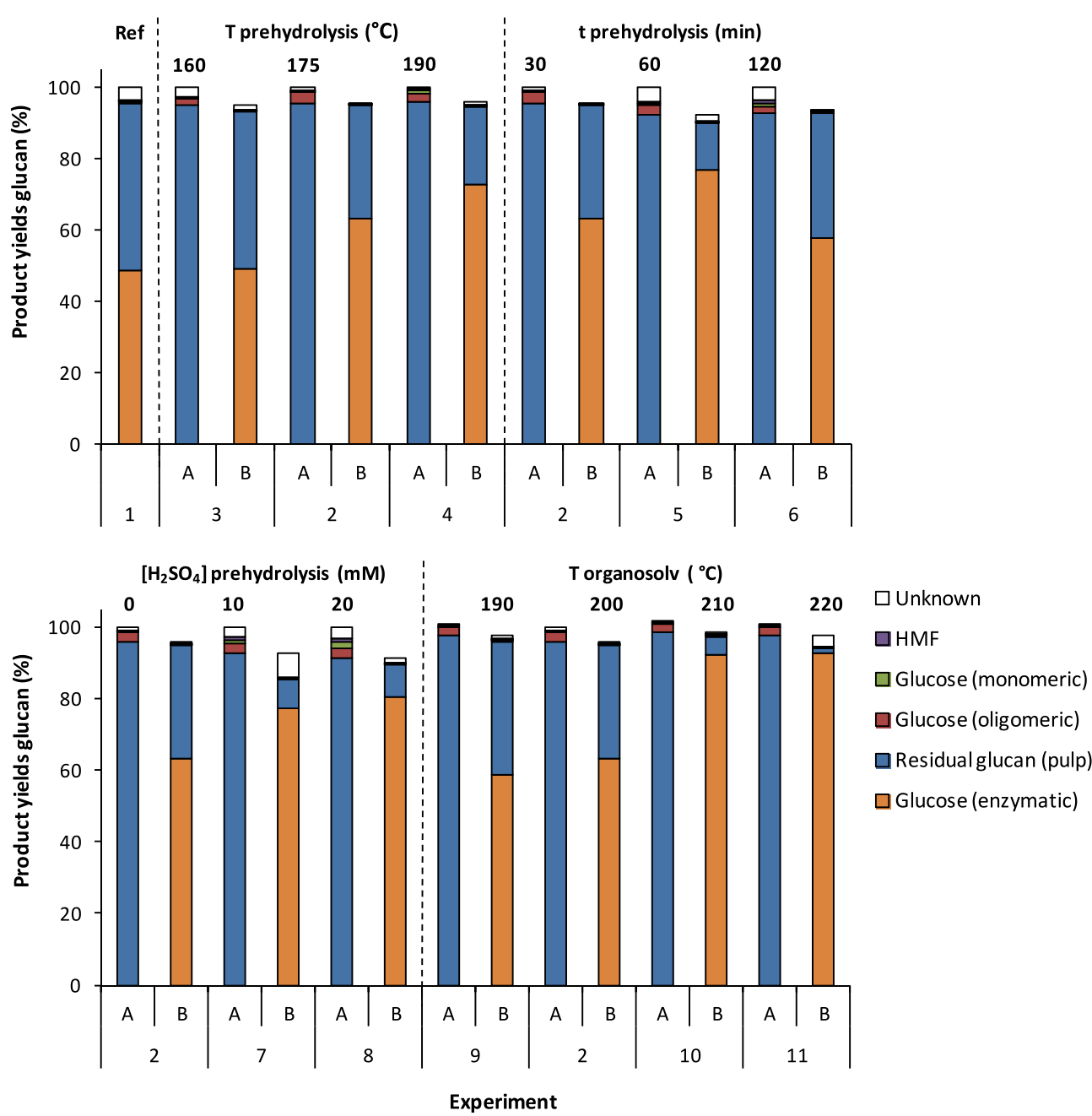

Fig. 5. Product distribution of glucan based on glucan content raw wheat straw. Yields:\% of theoretical maximum. (A) prehydrolysis. (B) organosolv delignification and enzymatic hydrolysis.

(Table 3, pH 4.2-4.6 for 2B-11B cf. pH 4.9 for 1). At more severe prehydrolysis conditions (i.e., higher temperature), delignification is reduced more strongly (to $43 \%$ at $190^{\circ} \mathrm{C}$ ). Apparently, the lignin becomes more stable (condensed) due to the aqueous pretreatment and is therefore harder to extract during the organosolv step. This phenomenon has also been reported by El Hage et al. (2010). In addition, the removal of the salts during prehydrolysis may play a role in reduction of subsequent organosolv delignification since salts have been reported to catalyze organosolv pulping (Yawalata and Paszner, 2004). In contrast to lignin removal, the overall xylan removal is obviously higher when prehydrolysis is included. Thus, the xylan content of the resulting organosolv pulp is lower $(3.8 \%$ at $\left.190^{\circ} \mathrm{C}\right)$ than without prehydrolysis $(18.3 \%$, Table 2$)$. The total glucan recovery is not affected by prehydrolysis at the conditions studied (glucan recovery: 93-95\%). Finally, prehydrolysis prior to organosolv delignification increases the enzymatic digestibility of the resulting pulp (up to $77 \%$ vs $51 \%$ based on the glucan content of the pulp, Fig. 6). Apparently, the reduced xylan content of the pulp and the changed nature of the lignin enhance the enzymatic digestibility in spite of the higher lignin content (17.8\% vs $9.1 \%$ for experiment 2).

\subsubsection{Reaction time}

In experiments 5 and 6 , the reaction time was extended to 60 and $120 \mathrm{~min}$ in an attempt to further increase the $44 \%$ yield of xylose obtained in experiment $2\left(30 \mathrm{~min}, 175^{\circ} \mathrm{C}\right)$. The xylan content of the pulp resulting from prehydrolysis decreases from $13.4 \%$ (30 $\mathrm{min}$ ) to $4.9 \%$ (120 $\mathrm{min}$ ) (Table 2 ). The xylan removal degree increases from 57 (30 min) to $86 \%$ (120 min) (Fig. 3). The yield of oligomeric xylose shows a maximum of $47 \%$ at $60 \mathrm{~min}$ and a strong decline to $8 \%$ upon extension of the reaction time to $120 \mathrm{~min}$. The yield of monomeric xylose, but also that of furfural, increase with reaction time from $2 \%$ and $3 \%$ (30 $\mathrm{min}$ ) to $16 \%$ and $26 \%$ (120 min), respectively. The loss of xylan derivatives to products like humins and lignin-furfural condensation products increases simultaneously to $34 \%$ at $120 \mathrm{~min}$. Overall, the highest yield of xylose has been obtained at $60 \mathrm{~min}(57 \%)$ as well as the highest yield of total identified products resulting from xylan (66\%).

Even at longer reaction times, no significant glucan hydrolysis occurs (Fig. 5). However, the formation of 'pseudo-lignin' is promoted by extending the reaction time to $120 \mathrm{~min}$ (at $120 \mathrm{~min}$, residual 'lignin' in pulp is $122 \%$ of lignin present in the raw material). As a consequence, the pulp yield of the 120 min experiment and its AIL content are even slightly higher than that of the 60 min experiment (Table 2).

A longer hemicellulose prehydrolysis time reduces the susceptibility of the resulting pulp to organosolv delignification. Residual lignin in the organosolv pulp increases from $40 \%$ (30 $\mathrm{min}$ ) to $66 \%$ (120 min) of the lignin present in the wheat straw. The AIL content of the organosolv pulp increases from $11.9 \%$ to $19.4 \%$. On the other hand, the xylan content decreases at the same time from $11.1 \%$ to $5.3 \%$. As a consequence, the enzymatic digestibility of the organo- 
Table 3

Liquors: $\mathrm{pH}$ and composition of prehydrolysis and organosolv liquors.

\begin{tabular}{|c|c|c|c|c|c|c|c|c|c|c|c|c|}
\hline \multicolumn{2}{|c|}{ Experiment ${ }^{\mathrm{a}}$} & \multirow[t]{3}{*}{$\mathrm{pH}(-)$} & \multicolumn{5}{|c|}{ 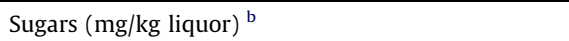 } & & \multirow{2}{*}{\multicolumn{4}{|c|}{ Others $(\mathrm{mg} / \mathrm{kg} \text { liquor })^{\mathrm{c}}$}} \\
\hline & & & \multicolumn{3}{|c|}{ Monomeric } & \multicolumn{3}{|c|}{ Oligomeric $^{\mathrm{d}}$} & & & & \\
\hline & & & Ara & Glc & Xyl & Ara & Glc & Xyl & Furfural & HMF & Acetic acid & Formic acid \\
\hline 1 & & 4.9 & 49 & 11 & 81 & 99 & 127 & 894 & 327 & 48 & 2617 & 798 \\
\hline \multirow[t]{2}{*}{2} & A & 4.2 & 824 & 5 & 457 & 649 & 1221 & 11868 & 528 & 62 & 1702 & 272 \\
\hline & B & 4.6 & 31 & 12 & 235 & 54 & 60 & 935 & 425 & 35 & 653 & 115 \\
\hline \multirow[t]{2}{*}{3} & A & $\mathrm{ND}^{\mathrm{e}}$ & 88 & 5 & 23 & 1025 & 853 & 272 & 47 & 22 & 781 & 86 \\
\hline & $\mathrm{B}$ & 4.6 & 53 & 10 & 156 & 80 & 65 & 1271 & 445 & 39 & 1852 & 444 \\
\hline \multirow[t]{2}{*}{4} & A & ND & 385 & 269 & 5087 & 39 & 1051 & 4714 & 4200 & 204 & 3821 & 815 \\
\hline & B & 4.4 & & 13 & 76 & 11 & 46 & 52 & 482 & 60 & 211 & f \\
\hline \multirow[t]{2}{*}{5} & A & 3.9 & 655 & 193 & 2566 & 221 & 1100 & 12307 & 1574 & 122 & 2598 & 561 \\
\hline & B & 4.5 & & 19 & 147 & & 74 & 473 & 354 & 44 & 302 & \\
\hline \multirow[t]{2}{*}{6} & A & 3.6 & 248 & 316 & 4238 & 7 & 832 & 2186 & 4384 & 263 & 3474 & 899 \\
\hline & B & 4.6 & & 21 & 65 & & 58 & 83 & 733 & 70 & 258 & \\
\hline \multirow[t]{2}{*}{7} & A & 3.6 & 1229 & 342 & 3524 & 238 & 1125 & 13034 & 1285 & 182 & 1620 & \\
\hline & B & 4.6 & 17 & 24 & 207 & 48 & 79 & 876 & 399 & 56 & 395 & \\
\hline \multirow[t]{2}{*}{8} & A & 2.9 & 1487 & 702 & 12445 & 177 & 1147 & 4782 & 2613 & 256 & 2126 & \\
\hline & B & 4.4 & 12 & 40 & 172 & & 86 & 315 & 379 & 73 & 226 & \\
\hline \multirow[t]{2}{*}{9} & A & 4.2 & 659 & 130 & 404 & 811 & 1040 & 11467 & 349 & 41 & 946 & 150 \\
\hline & B & 4.6 & 44 & 17 & 187 & 52 & 46 & 806 & 237 & 17 & 330 & \\
\hline \multirow[t]{2}{*}{10} & A & 4.2 & 964 & 194 & 592 & 551 & 1053 & 11909 & 473 & 62 & 1564 & 263 \\
\hline & B & 4.4 & 23 & 19 & 428 & 33 & 62 & 749 & 546 & 62 & 654 & \\
\hline \multirow[t]{2}{*}{11} & A & 4.0 & 934 & 189 & 606 & 539 & 1020 & 11829 & 490 & 62 & 1580 & 287 \\
\hline & B & 4.2 & 7 & 22 & 244 & 16 & 69 & 451 & 522 & 92 & 795 & \\
\hline
\end{tabular}

${ }^{a} \mathrm{~A}=$ prehydrolysis step. $\mathrm{B}=$ organosolv delignification step.

b Only major sugars shown. Abbreviations used: arabinose (Ara), xylose (Xyl), and glucose (Glc).

c In all samples the concentration of levulinic acid was below the detection limit of $125 \mathrm{mg} / \mathrm{kg}$.

d Expressed as monomer equivalents.

e Not determined.

${ }^{\mathrm{f}}$ Empty cell: concentration below detection limit. Detection limit depends on the matrix.

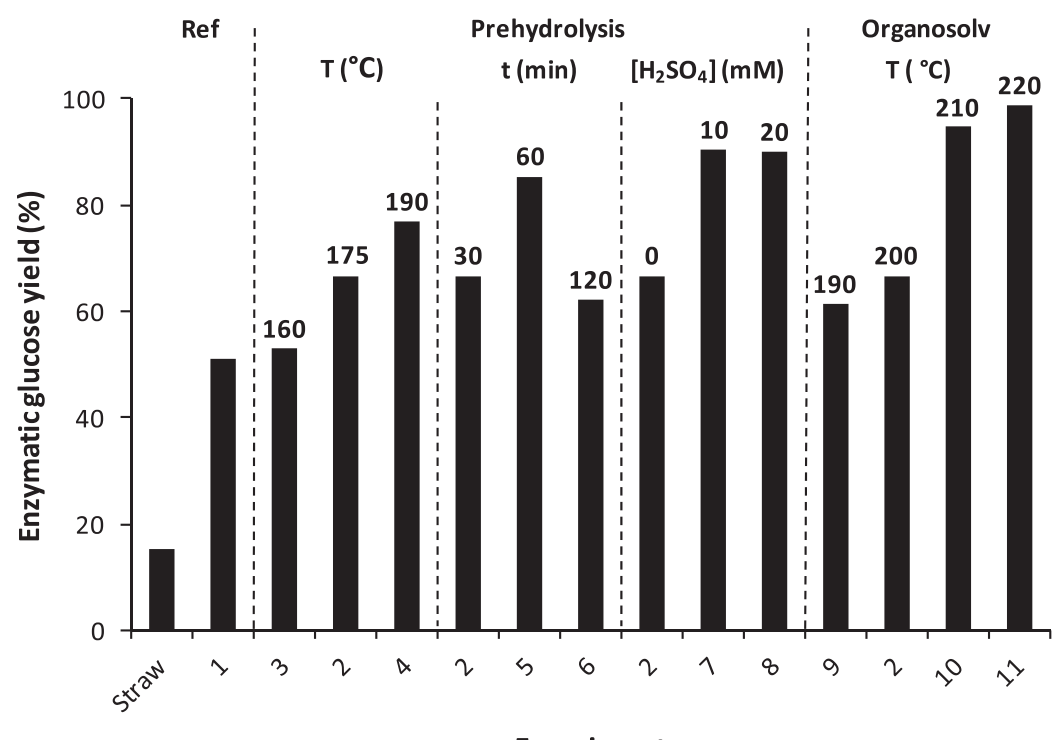

\section{Experiment}

Fig. 6. Enzymatic digestibility of raw wheat straw and solid products. Enzymatic glucose yield: maximum glucose yield during $72 \mathrm{~h}$ of enzymatic hydrolysis based on glucan content of substrate. Yield:\% of theoretical maximum.

solv pulps increases from $67 \%$ (30 $\mathrm{min})$ to $85 \%$ (60 $\mathrm{min})$. The enzymatic digestibility of sample 6 (120 min) is only $62 \%$ (Fig. 6). However, it seems questionable whether this low number is correct. The reference sample in this enzymatic hydrolysis series (see Section 2.3.4) shows a significantly lower enzymatic glucose yield than average (data not shown) and has been considered an outlier in determination of the experimental error involved (see Section 2.4).

\subsubsection{Addition of $\mathrm{H}_{2} \mathrm{SO}_{4}$}

The use of sulfuric acid during the prehydrolysis step (experiments 7 and 8) clearly promotes xylan hydrolysis up to $83 \%$
(20 $\mathrm{mM} \mathrm{H}_{2} \mathrm{SO}_{4}$ ). At this acid dose, also the maximum yield of monomeric xylose (49\%) has been obtained. The yield of oligomeric xylose shows a maximum at $10 \mathrm{mM} \mathrm{H}_{2} \mathrm{SO}_{4}$ (49\%). The maximum yield of total monomeric and oligomeric xylose is $67 \%$ at $20 \mathrm{mM}$ $\mathrm{H}_{2} \mathrm{SO}_{4}$, which is also the maximum obtained during the prehydrolysis step in this study. Addition of $\mathrm{H}_{2} \mathrm{SO}_{4}$ has a small effect on the glucan recovery, which decreases to $91 \%$ at a $20 \mathrm{mM}$ dose. Products formed include $3 \%$ oligomeric glucose, $1 \%$ monomeric glucose and $1 \%$ HMF. No indications for increased formation of pseudo-lignin have been found. The lignin recovery of the prehydrolysis step is $101 \%$ at $20 \mathrm{mM} \mathrm{H}_{2} \mathrm{SO}_{4}$. 
Table 4

Example of mass yields based on dry raw wheat straw (experiment 8). Main products given in bold.

\begin{tabular}{|c|c|c|c|c|c|c|c|}
\hline \multirow[t]{2}{*}{ (kg/kg Dry wheat straw) } & \multicolumn{2}{|l|}{ Input } & \multicolumn{5}{|l|}{ Output } \\
\hline & Wheat straw & & Prehydrolysis & & Organosolv & & Enz. hydr. \\
\hline \multicolumn{8}{|l|}{ Solids } \\
\hline Wheat straw (pulp) & 1.00 & & 0.59 & & 0.49 & & \\
\hline Consisting of: Glucan & & 0.35 & & 0.32 & & 0.31 & \\
\hline Xylan & & 0.21 & & 0.04 & & 0.02 & \\
\hline Lignin & & 0.16 & & 0.16 & & 0.08 & \\
\hline Other & & 0.28 & & 0.07 & & 0.08 & \\
\hline Lignin precipitated & & & & & 0.07 & & \\
\hline \multicolumn{8}{|l|}{ Liquor } \\
\hline Glucose (mon.) & & & 0.01 & & 0.00 & & 0.31 \\
\hline Glucose (olig.) & & & 0.01 & & 0.00 & & \\
\hline Xylose (mon.) & & & 0.12 & & 0.00 & & \\
\hline Xylose (olig.) & & & 0.05 & & 0.00 & & \\
\hline Arabinose (mon.) & & & 0.01 & & 0.00 & & \\
\hline Arabinose (olig.) & & & 0.00 & & a & & \\
\hline Furfural & & & 0.03 & & 0.00 & & \\
\hline $\mathrm{HMF}$ & & & 0.00 & & 0.00 & & \\
\hline Acetic acid & & & 0.02 & & 0.00 & & \\
\hline Formic acid & & & a & & a & & \\
\hline Levulinic acid & & & a & & a & & \\
\hline Sum & 1.00 & & 0.83 & & $0.58^{\mathrm{b}}$ & & \\
\hline
\end{tabular}

a Below detection limit.

b Based on dry feedstock (i.e., prehydrolysis pulp $8 \mathrm{~A}$ ): $98 \% \mathrm{w} / \mathrm{w}$.

Addition of sulfuric acid during the prehydrolysis step results in an organosolv pulp with a lower xylan content $(5.0 \%$ at $20 \mathrm{mM})$, but a higher lignin content (15.2\%) (Table 2). The use of $\mathrm{H}_{2} \mathrm{SO}_{4}$ in prehydrolysis has no clear effect on the delignification during the organosolv step $(58 \%(0 \mathrm{mM}), 60 \%(10 \mathrm{mM})$ and $52 \%(20 \mathrm{mM}))$. It might be that the use of acid during prehydrolysis somewhat reduces delignification during organosolv, similarly to reaction temperature. However, this cannot be concluded from the experiments performed. The enzymatic digestibility has been found to increase from $67 \%\left(0 \mathrm{mM} \mathrm{H}_{2} \mathrm{SO}_{4}\right)$ to $90 \%(10 \mathrm{mM}$ and $20 \mathrm{mM}$ $\mathrm{H}_{2} \mathrm{SO}_{4}$ ) (Fig. 6). The glucan recovery of organosolv experiment $7 \mathrm{~B}$ is only $92 \%$ compared to $98-100 \%$ for all other organosolv experiments at $200{ }^{\circ} \mathrm{C}$ following prehydrolysis. As a result, the maximum overall enzymatic glucose yield is $80 \%$ from raw wheat straw to glucose for experiment 8 in spite of the slight glucan hydrolysis during experiment $8 \mathrm{~A}$. The reason for the somewhat lower glucan recovery of experiment $7 \mathrm{~B}$ is unknown.

\subsection{Organosolv delignification following prehydrolysis}

As discussed in Section 3.3, application of hemicellulose prehydrolysis before organosolv delignification reduces the delignification degree during organosolv due to the formation of lignin condensation products during prehydrolysis. In the final series of experiments, we tried to compensate for this reduction by increasing the severity of the organosolv delignification step. The process temperature of the organosolv fractionation step following prehydrolysis at $175^{\circ} \mathrm{C}$ was varied between 190 and $220^{\circ} \mathrm{C}$ (experiments 9-11).

A higher organosolv reaction temperature improves both the delignification, the hydrolysis of residual xylan and the enzymatic digestibility of the resulting pulp. The increase in enzymatic digestibility between 200 and $210^{\circ} \mathrm{C}$ is remarkable (Fig. 6). At $220^{\circ} \mathrm{C}$, the overall delignification is similar to that of organosolv fractionation without prehydrolysis (i.e., delignification 69\% (exp 11) compared to $67 \%$ (exp 1), Fig. 4). At this temperature, $85 \%$ of the residual xylan is hydrolyzed, $96 \%$ of the glucan is recovered and $99 \%$ of the glucan in the resulting pulp is enzymatically digestible (Fig. 6). The overall enzymatic glucose yield from feedstock to glucose is $93 \%$. However, even at $220^{\circ} \mathrm{C}$, the lignin yield is lower (60\%) than that of reference experiment 1 (74\%) (Fig. 4). Since the delignification degree is similar, apparently the lignin precipitation efficiency is lower. Possibly, the high temperature applied causes formation of smaller lignin fragments, which are more difficult to precipitate from the organosolv liquor upon water addition.

\subsection{Product yields}

Table 4 shows the mass yields of the products for experiment 8 . Experiment 8 (i.e., prehydrolysis with $20 \mathrm{mM} \mathrm{H}_{2} \mathrm{SO}_{4}$ followed by organosolv delignification at $200{ }^{\circ} \mathrm{C}$ ) has resulted in the highest yield of xylose obtained during this study and is therefore selected as example. The total mass yield of all products resulting from the prehydrolysis step is $83 \%$. Components that are not taken into account for this total mass yield include the soluble part of the ash fraction of the wheat straw, organic water-soluble extractives and gases formed. The total mass yield of all products resulting from the organosolv step is $98 \%$ based on the feedstock for the organosolv step. At the process conditions of experiment 8 , the yields of the main products by prehydrolysis-organosolv fractionation are $0.31,0.17$ and $0.07 \mathrm{~kg} / \mathrm{kg}$ dry straw of glucose, xylose and lignin, respectively.

\section{Conclusions}

The use of a prehydrolysis step prior to organosolv delignification of wheat straw was found to improve the yield of xylose and the enzymatic cellulose digestibility. A maximum yield of $67 \%$ xylose (oligomers) or $0.17 \mathrm{~kg} / \mathrm{kg}$ dry straw was obtained by prehydrolysis at $175^{\circ} \mathrm{C}$ using $20 \mathrm{mM} \mathrm{H}_{2} \mathrm{SO}_{4}$. Increasing the organosolv delignification temperature from 200 to $220^{\circ} \mathrm{C}$ resulted in a maximum enzymatic glucose yield of $93 \%$ or $0.36 \mathrm{~kg} / \mathrm{kg}$ straw. However, the use of a prehydrolysis step reduced the lignin yield by subsequent organosolv treatment probably due to the formation of 'pseudo-lignin' and lignin recondensation during prehydrolysis. 


\section{Acknowledgements}

The authors thank Cédric Bara, Claire-Line Blanc, Ron van der Laan, and Hans Reith for their contribution to this work. Ben van Egmond and Karina Vogelpoel-de Wit are acknowledged for their analytical work. This research was funded by the Dutch Ministry of Economic Affairs, Agriculture and Innovation as part of the Biomass research program of ECN.

\section{References}

Aravamuthan, R., Chen, W., Zargarian, K., April, G., 1989. Chemicals from wood: prehydrolysis/organosolv methods. Biomass 20, 263-276.

Brosse, N., El Hage, R., Sannigrahi, P., Ragauskas, A., 2009. Dilute sulphuric acid and ethanol organosolv pretreatment of Miscanthus x Giganteus. Cellul. Chem. Technol. 44, 71-78

Carvalheiro, F., Duarte, L.C., Gírio, F.M., 2008. Hemicellulose biorefineries: a review on biomass pretreatments. J. Ind. Sci. Res. 67, 849-864.

Chen, H., Liu, L., 2007. Unpolluted fractionation of wheat straw by steam explosion and ethanol extraction. Bioresour. Technol. 98, 666-676.

Diaz, M.J., Huijgen, W.J.J., Van der Laan, R.R., Reith, J.H., Cara, C., Castro, E., 2011. Organosolv pretreatment of olive tree biomass for fermentable sugars. Holzforschung 65, 177-183.

El Hage, R., Chrusciel, L., Desharnais, L., Brosse, N., 2010. Effect of autohydrolysis of Miscanthus x giganteus on lignin structure and organosolv delignification Bioresour. Technol. 101, 9321-9329.

Garrote, G., Domínguez, H., Parajó, J.C., 1999. Hydrothermal processing of lignocellulosic materials. Holz als Roh- und Werkstoff 57, 191-202.

Hendriks, A., Zeeman, G., 2009. Pretreatments to enhance the digestibility of lignocellulosic biomass. Bioresour. Technol. 100, 10-18.

Huijgen, W.J.J., Reith, J.H., Uil den, H., 2010. Pretreatment and fractionation of wheat straw by an acetone-based organosolv process. Ind. Eng. Chem. Res. 49, 1013210140.

Huijgen, W.J.J., Smit, A.T., Reith, J.H., Uil den, H., 2011. Catalytic organosolv fractionation of willow wood and wheat straw as pretreatment for enzymatic cellulose hydrolysis. J. Chem. Technol. Biotechnol. 86, 1428-1438.

Kamm, B., Gruber, P.R., Kamm, M.E., 2006. Biorefineries - Industrial processes and products. Status quo and future directions. Wiley-VCH, Weinheim, Germany.

Li, J., Gellerstedt, G., 2008. Improved lignin properties and reactivity by modifications in the autohydrolysis process of aspen wood. Ind. Crop. Prod. $27,175-181$.

Li, J., Henriksson, G., Gellerstedt, G., 2007. Lignin depolymerization/ repolymerization and its critical role for delignification of aspen wood by steam explosion. Bioresour. Technol. 98, 3061-3068.
Liu, C., Wyman, C.E., 2004. The effect of flow rate of very dilute sulfuric acid on xylan, lignin, and total mass removal from corn stover. Ind. Eng. Chem. Res. 43 2781-2788.

Lora, J.H., Wayman, M., 1978. Delignification of hardwoods by autohydrolysis and extraction. TAPPI J. 61, 47-50.

Mosier, N., Wyman, C.E., Dale, B.E., Elander, R.T., Lee, Y.Y., Holtzapple, M., Ladisch, M.R 2005. Features of promising technologies for pretreatment of lignocellulosic biomass. Bioresour. Technol. 96, 673-686.

National Renewable Energy Laboratory (NREL). Chemical analysis and testing laboratory analytical procedures. NREL, Golden, CO., USA. <http:// www.nrel.gov/biomass/analytical_procedures.html>. 2009.

Pan, X., Arato, C., Gilkes, N., 2005a. Biorefining of softwoods using ethanol organosolv pulping - preliminary evaluation of process streams for manufacture of fuel-grade ethanol and co-products. Biotechnol. Bioeng. 90, $473-481$.

Pan, X.J. Xie, D., Gilkes, N., Gregg D.J., Saddler, J.N., 2005b. Strategies to enhance the enzymatic hydrolysis of pretreated softwood with high residual lignin content Appl. Biochem. Biotechn. 121, 1069-1079.

Romaní, A., Garrote, G., López, F., Parajó, J.C., 2011. Eucalyptus globulus wood fractionation by autohydrolysis and organosolv delignification. Bioresour. Technol. 102, 5896-5904.

Ruiz, H.A., Ruzene, D.S., Silva, D.P., Macieira da Silva, F.F., Vicente, A.A., Teixeira, J.A., 2011. Development and characterization of an environmentally friendly process sequence (autohydrolysis and organosolv) for wheat straw delignification. Appl. Biochem. Biotechnol. 164, 629-641.

Sluiter, J.B., Ruiz, R.O., Scarlata, C.J., Sluiter, A.D., Templeton, D.W., 2010 Compositional analysis of lignocellulosic feedstocks. 1. Review and description of methods. J. Agric. Food Chem. 58, 9043-9053.

Taherzadeh, M.J., Karimi, K., 2008. Pretreatment of lignocelluosic wastes to improve ethanol and biogas production: a review. Int. J. Mol. Sci. 9, 1621-1651.

Talebnia, F., Karakashev, D., Angelidaki, I., 2010. Production of bioethanol from wheat straw: an overview on pretreatment, hydrolysis and fermentation. Bioresour. Technol. 101, 4744-4753.

Technical Association of the Pulp and Paper Industry (TAPPI). Useful method 250: acid-soluble lignin in wood and pulp. 1976.

Wild de, P.J., Uil den, H., Reith, J.H., Lunshof, A., Hendriks, C., Eck van, E.R.H., Heeres, H.J., 2009. Bioenergy II: biomass valorisation by a hybrid thermochemical fractionation approach. Int. J. Chem. React. Eng. 7, A51.

Wyman, C.E., Dale, B.E., Elander, R.T., Holtzapple, M., Ladisch, M.R., Lee, Y.Y., 2005. Coordinated development of leading biomass pretreatment technologies. Bioresour. Technol. 96, 1959-1966.

Yawalata, D., Paszner, L., 2004. Cationic effect in high concentration alcoho organosolv pulping: the next generation biorefinery. Holzforschung 58, 7-13.

Zakzeski, J., Bruijnincx, P.C.A., Jongerius, A.L., Weckhuysen, B.M., 2010. The catalytic valorization of lignin for the production of renewable chemicals. Chem. Rev. $110,3552-3599$

Zhao, X., Cheng, K., Liu, D., 2009. Organosolv pretreatment of lignocellulosic biomass for enzymatic hydrolysis. Appl. Biochem. Biotechnol. 82, 815-827. 